\title{
Strengthening Small Scale Crop Farming For Pro-Poverty Oriented Growth
}

\author{
${ }^{1}$ Onoh, P.A., ${ }^{1}$ Peter-Onoh,C.A., ${ }^{1}$ Ngwuta, A. A., ${ }^{1}$ Obiefuna,J.C., ${ }^{1}$ Ugwoke, F. \\ O., ${ }^{1}$ Echetama, J. A., ${ }^{1}$ Nze, E. O., ${ }^{1}$ Ekwugha, E. U. \\ Federal University of Technology, Owerri, Imo State Nigeria.
}

\begin{abstract}
Most Africans live in rural areas and depend on agriculture for their livelihoods. These predominantly small-scale farmers face many challenges, including food security, rising poverty and natural resource degradation. To increase the productivity, profitability and sustainability for the farmer who needs greater access to affordable yield-enhancing inputs, including well-adapted seeds and new methods of integrated soil fertility management as well as output markets where they can convert surplus production into cash. To address these needs, the Rockefeller foundation established the alliance for a Green revolution in Africa. In Nigeria, the federal government established so many Agricultural Extension organizationsand credit facilities e.g. Operation Feed the Nation (O.F.N), Green Revolution Programme(GRP), Agricultural Development Programme (ADP), National Accelerated Food Production Programme(NAFPP), Nigerian Agricultural and Co-operative Bank (NACB)etc, to strengthen small-scale crop farming to support work across all key aspects of Nigeria agricultural value chain. These organizations were to lift millions of small-scale farmers and their families out of poverty and hunger.

Keywords: Agriculture, crop, land, rural area, small-scale farmers,
\end{abstract}

\section{Introduction}

Agriculture is critical for both human welfare and economic growth in Arica. In sub-Saharan Africa, roughly two-thirds of the population live in rural areas and are dependent on agriculture for their livelihoods; nearly less than $\$ 1 /$ day; and one-third are undernourished [1]. Most of this poverty and hunger is rural, and the root cause is lack of sufficient food production and income generation from small-scale farming [2].

The Nigerian population is largely rural. Rural population constitutes over $70 \%$ of the total population [3]. While the main occupation of the rural people is agriculture and majority of those living in urban areas engage in different businesses. The farming population is estimated to beabout $13 \%$ of the total population [4]. The Nigerian agricultural system has been described in various ways because of the small size of holdings. It has often been referred to as subsistence, traditional or peasant agriculture. Strictlyspeaking, a subsistence farmer consumes over $90 \%$ of his production with little or nothing for sale. A peasant farmer's priority is the provision of food for the family before considering the sale of the surplus to the market. The Nigerian small farmers constitute an important component of the Nigerian economy as over $90 \%$ of Nigeria's total agricultural production is accounted for by farmers that cultivate an average of about two hectares of lands and over $60 \%$ of the country's population earn their living from products of small-scale farmers [5]. These farmers are currently dominating Nigeria agriculture and the situation is likely to remain.

\section{Nigeria Agricultural Environment}

Nigeria has tropical climate, with an average temperature of $32^{\circ} \mathrm{c}, 900 \mathrm{~km}$ ofcoastal waters and a good network of inland rivers with extensive capacity for fish production and crop production [6]. There are essentially six agricultural sub-zones, namely Humid forest, Southern Guinea savanna, Northern Guinea savanna, Mid attitude savanna, derived Savanna and Semi-arid. These sub-zones differ in rainfall, solar radiation, length of growing season and cropping systems. Annual rainfall ranges from $2.5 \mathrm{~mm}$ in the south-east to $6.0 \mathrm{~mm}$ in the north. The climate and vegetation are capable of supporting production of different crops and livestock, with poultry and pigs dominating in the south and cattle and small ruminants in the north. Nigeria has a land mass of 90.8 million hectares, over $80 \%$ (73 million ha) of which is agricultural land with 30 million ha as cultivable land [7].

In the south, the mixed cropping system consists of root crops, plantain, tree crops and occasional stands of maize and vegetables. The North is characterized by mixtures of cereals, leguminous grains and fibres. The middle belts are a transition zone where a wider variety of crop mixture can be found.

Resource poor farmers have consistently stuck to mixed cropping practices because of the following:

i. Mixed cropping is said to give high yields and hence higher monetary returns than sole cropping

ii. Crop mixtures make more efficient use of environmental resources (light, water, nutrients) and labour 
iii. Pests and diseases may not spread as rapidly in mixtures because of differential susceptibility to pest and pathogens.

iv. Mixed cropping provides insurance against crop failure and thereby ensures total subsistence needs of the farmers

v. The system provides effective coverage for the soil and thereby minimizes soil erosion and exposure to solar radiation is minimized.

vi. It provides a steady range of products for the family and helps to spread labour cost more evenly throughout the cropping season.

\subsection{SEARCH FOR SMALL-SCALE FARMERS (RESOURCE - POOR FARMERS)}

Attempting to define the resource poor farmer is like making frantic effort to find the 'common man' in Nigeria. If we consider a whole range of agricultural production resources constraints e.g. land, labour, capital, water, fertilizer, improved varieties of seeds, chemicals etc, it will be difficult to exclude any farmer in the country from the group of "resource poor farmer" (small- scale farmers). The resources endowments of farmers vary in terms of size of holdings, ownership of work bulls and availability of credit, even though all may be poor in the general sense.

\section{3 SOME CHARACTERISTICS OF SMALL- SCALE FARMERS}

i. Small- scale farmers consume the major portion of their produce with little or no market surplus.

ii. They have limited funds to purchase inputs.

iii. The level of technology is based towards low - risk, low production, and traditional techniques leading to low productivity.

iv. Lack collaterals to secure loans from financial institutions etc.

The objectives of this review is to strengthen small scale crop farming for pro-poverty oriented growth and lift millions of small-scale farmers and their families out of poverty and hunger.

\section{Production Resources}

Land-Land was the most important input of small farmers, but it was generally not believed to be abundant, relative to other production inputs. It was estimated that only less than $40 \%$ of the 71 million hectares were cultivated ([8]. It must be stressed that the apparent abundance of land in Nigeria was limited by population pressure, livestock expansion, desertification and deforestation. As a result of land tenure system, size of farm land was generally small and field highly fragmented.

Labour-Labour was another important input of small scale farms. Labour is said to be a major constraint limiting the farm size. The amount of activity that takes place in the rest of the year is determined by the amount of labour that a family can afford during the peak season. Production under peasant farming system is labour intensive. Familylabour forms the main source of farm labour supply. Where hired labour is used, cost of hired labour constitutes over $70 \%$ of the total cost of production.Nigerian agriculture is virtually unmechanized and human labour accounts for almost $90 \%$ of all farm operations. In areas where partial mechanizations is possible in form of animal traction and tractorazation, human labour is still required up to about $70 \%$ of all the operations for planting, weeding and harvesting [8].The distribution of land in the country is skewed towards few farmers having large hectares of lands while the majority of the poor farming households cultivate less than 2 hectares.

\section{Capital}

A typical Nigerian farmer uses little amount of capital. The use of agricultural power equipment and machinery is almost non-existent except in selected areas of the northern parts of the country where animal traction is being used. There is very low capital investment in farming tools and equipment which consists of hoes and cutlasses. Expenditures on purchased inputs like fertilizers, pesticides and improved seeds and seedlings usually constitute minor components of the total cash expenditure. Traditional use of capital (cash and credits) is for hiring labourand meeting household expenses and cash transfer within and between families are quite frequent and important in meeting farm expenses. Credits system opportunities open to farmers include; agricultural loans from the Nigerian Agricultural, Cooperative and Rural Development Bank (NACRDB), Agricultural credit GuaranteeScheme, and Micro Finance Banks. . 


\section{Fertilizer}

Organic manure and droppings from roamingcattle are commonly used by small farmers especially in the northern parts of the country. The use of chemical fertilizer has been on the increase as a result of the following: Awareness created by Operation Feed the Nation (OFN), National Accelerated Food Production Project (NAFPP)and the establishment of the Agricultural Development Projects (ADPs). Two major issues concerning fertilizers that were of importance to the small farmers were subsidy removal and privatization of fertilizer procurement and distribution. Input subsidies have been favoured to enhance adoption of new inputs. Farmers were already used to it and it was the most readily adopted technology. The current problems which included the growing black market in fertilizer, misallocation, hoarding, and the budgetary burden of subsides were making the government to consider seriously subsidy reduction/removal. There was acute scarcity of fertilizer at farm level. The challenge was for the farming system research practitioners to find alternative to chemical fertilizers.

\section{Water}

Rainfall was one of the main determinations of the nature of crops grown in Nigeria. Rainfall decreases in duration and intensity as one moves from the south to the northern parts of the country. Until recent years, water has not been given enough attention as an important impact to increase the stabilized crop yields. The Sahel drought of early 1970's among other factors gave impetus to heavy public investment. Emphasis has been given to the development of irrigation especially in the drier northern parts of the country

\section{Challenges}

Low farm productivity in Africa has many causes, including use of traditional crop varieties, increasingly depleted soils, shrinking plots of land, scarce and unreliable water supply, crop losses from pests and diseases, inequitable land distribution patterns inefficient and unfair markets, and poor agricultural and transportation infrastructure, and finally inadequate post harvest technology ([9].

The low performance of agriculture in Africa is the main cause of its food insecurity and slow economic growth. Despite periodic local progress, average yields for sub-Saharan Africa has not increased for decades whereas yields in Asia and Latin America have shown a steady increase [10]. Africa has tried to keep up with its growing population's demand for more food by significantly expanding the area of production, thus contributing to land degradation. More than three quarters of the farmland in sub- Saharan Africa has been depleted of basic plant nutrients and farmers increasingly face severe soil fertility problems [11].

In Nigeria agricultural business is vested mainly with small scale farmers, who are found mostly in rural communities and produce for family consumption and surplus sold and raw materials needed by industrial sector of the economy [12]. In discharging these responsibilities, they face a lot of problems, these include;

i. Inadequate or restricted access to capital and limited access to credit facilities for expansion, input etc.

ii. [6] attributed the downward trend in per capita food production whichdemands a continuous cropping on the soil without adequate fallow periods resulting into infertile soil.

iii. Nature of land tenure in the country.

iv. Inadequate post-harvest technology e.g. Storage, processing and marketing.

v. Irrigation facilities for dry season farming.

vi. Access rural roads to facilitateincreased food production and ease evacuation to the urban cities.

\section{Strengthening Small Scale Farming}

The green revolution was one of the great technological success stories of the second half of the $20^{\text {th }}$ century. In many developing countries of Asia and Latin America, the genetic improvement of staple food crops, combined with strengthened institutions enabled overall food production to keep pace with population growth while both more than doubled [13]. When food production rises through such increases in land, labour and productivity, the rural poor gain. Thus the benefit of the green revolution reached many of the world's poorest people and the proportion of the population in Asia that was under-nourished declined from $41 \%$ in 1960 to $16 \%$ in 2000 [1]. Massive famine that was predicted for the world's two populous countries, India and China, were averted.In contrast to Asia and Latin America, Africa has not experienced a sustained green revolution despite considerable funding and efforts aimed at promoting agricultural development on the continent. Increase in crop yields had occurred in Africa but in recent years tended to be project specific with little farmer adoption of yield enhancing technologies beyond the project's geographic focus and time frame.The conditions for improving agricultural production in Africa were substantially different from and more challenging than those that existed in Asia. Rainfall was often too little or too much and there were little irrigated lands. The rural population was more dispersed. Labour was scare and labour saving mechanization mostly absent. The cost of inputs was high, and there were few roads and rail lines providing access to markets. 
Also there were much more diverse sets of agro ecologies and cropping systems than Asia. In fact, the increase in production that occurred in Africa was largely as a result of the expansion of the area committed to crop production rather than increase in yields. Food production did not keep pace with population growth and subSaharan Africa remained the only region where average yields were stagnant and food production per capital steadily declined [14].This type of green revolution that rapidly spread across Asia raised agricultural productivity and laid the foundation for broader economic growth andto date, by passed Africa ([9].

\section{V.1.Building The Rockefeller Foundation Model In Africa}

The Rockefeller foundation has a long history of helping to build the national and international research resources necessary to generate and disseminate agricultural interventions that can increase the production, profitability and sustainability of small scale farms in developing countries. The programme strategy was based on a rather simple theory of change referred to as "Market-led technology adoption as depicted in fig 1.

Enhanced soil productivityBetter markets Resilient crop varieties

Fig.1

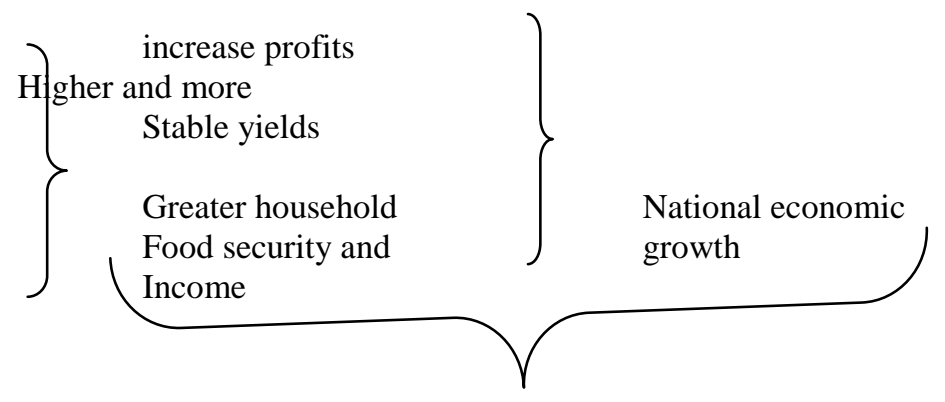

There are three basic components:

a. To help farmers increase the yield potential of their fields by enhancing soil productivity through innovative farming practices that supply adequate plant nutrients, improve the land's water-holding capacity and, are labour saving.

b. To help farmers realize a higher proportion of their farms potential yields by planting more resilient varieties of Africa's staple food crops that significantly reduce losses and increase the stability of yields while meeting human nutritional needs and consumer preferences.

c.Helping to build and make more equitable both the input markets that can deliver better seeds, small fertilizer packets and other inputs to farmers and the output markets that enable farmers to convert surplus production into profits and to generate greater income from cash crops and livestock.Enhanced soil productivity combined with more resilient crop varieties enables farmers to obtain higher and more stable yields. In the presence of fairer and more efficient markets, this leads to increased farm profit, which encourages even further adoption of yields enhancing technologies, higher yields and increased profits which provide farm householdings with greater food security and incomes and stimulate national economic growth.

\section{V.2.NIGERIAN EFFORTS IN STRENGTHENING SMALL- SCALE FARMING}

Nigeria may be described as a country in transition. She has been experiencing much revolution in nearly all her economic sectors especially in agricultural production. There is every amount of need to strengthen small-scale farmers so as to accelerate the country'seconomic growth and to improve the nutrition and well-being of Nigerians.

In trying to strengthen small- scale farming in Nigeria, so many strategies have been used. Some of these strategies looked like panic half measures.

Some reasons addressed for this sad situation of affairs are:

a.These efforts were sometimes not addressed to the real farmers.

b.These efforts were not properly co-ordinated.

c. Proper extension techniques were not employed.

These efforts were as follows:

\section{V.3.THE NIGERIAN FARM SETTLEMENTS SCHEME}

Farm settlement schemes were set up in the Eastern, Western and Mid-Western Regions in Nigeria. Essentially, the scheme was conceived as a group of small farmers who owned and operated their land individually but pooled their resources in a co-operative spirit to provide common services such as purchasing inputs and processing of produce [15]. One of the stated objectives of both the Eastern and Western Nigeria schemes were to provide employment and means of livelihood for primary school leavers who could not be absorbed into industry, public service and commercial houses. In the scheme, the minimum entrance age into the 
settlements was initially fixed at 16 . Boys at this age were undecided on their future career and according to [16]were drifted to the settlements in order to gain monthly allowance paid to settlers and use the settlements as a spring- board to another occupations.

\section{FAILURE}

Failure was attributed to a number of factors which included:

Inefficient management, care free attitude of the setlters and the belief of many of the farmers that farming was not a viable occupation ([17]. [16] reported that apart from the high expenses and various technical deficiencies of farm training institutes, it was asking for psychological impossibilities to expect youths 15-20 years of age to fully comprehend or to willingly commit themselves to the serious responsibilities which they were being called upon to accept both at the training institutes and at the farms.

\section{V.4 .OPERATION FEED THE NATION (OFN) PROGRAMMES}

The Operation Feed the Nation programme (OFN): The programme was aimed at making the nation less reliant on imported food. It was launched on May $21^{\text {st }} 1976$ and was specifically concerned with those aspects of agricultural development which yielded quick returns. These included fertilizer, pest control, use of improved seeds, vegetable production, poultry, fisheries, and agro service centers.

Specially the programme sought to:

1. encourage the sector of people relies on buying food to grow its own food.

2. mobilize the nation towards self-sufficiency and self-reliance in food;

3. encourage general pride in agriculture and

4. encourage balanced nutrition and thereby produce a healthy nation.

The failure was due to organizational problems and noneinvolvement of agricultural extension staff in the programme.

\section{V .5.GREEN REVOLUTION PROGRAMME}

The scheme was intended to replace theO.F.N. It was Launched on Monday April $14^{\text {th }}, 1980$. The programme was to bridge the gap between the high yields recorded on farmer's field. The council was also to undertake livestock development and credit mobilization and subsequent disbursement of same of farmers. On agricultural marketing, commodities like palm product, grains, rice, groundnut etc from the farmers to encourage them. It is however, indisputable that most of these lofty ideas were not translated into reality. Perhaps one of the main reasons why the scheme did not achieve much was that it failed to focus attention on the small scale farmers by way of provision of the much needed extension support and diversion of funds or resources, and also change in government halted the programme.

\section{V. 6.NATIONAL ACCELERATED FOOD PRODUCTION PROGRAMME (NAFPP)}

The NAFPP was described as the forerunner of the green revolution. It was initiated in 1973 by the federal government of Nigeria to accelerate the production of six major crops in Nigeria, namely rice, maize. Cassava, sorghum, millet and wheat. According to [18], the aim was to increase the farm yields of small scale farmers by their adoption of improved varieties which were responsive to nitrogen and improved management, by developing a well organized and trained extension staff and farmers and by developing effective support agencies to supply all the productions imputs, arrange storage and marketing.

\section{Objectives of the Progamme}

(1) To increase national food production primarily though increasing yield per hectare of the small scale farmers.

(2) To use a package of technology that can triple or quadruple traditional yields of crop grown by cooperating framers.

It succeeded in bringing researchers, extension workers and farmers together in order to improve food production but focused on mono-cropping so it gradually died off as an extension strategy.

\section{V.7. THE INTEGRATED AGRICULTURAL DEVELOPMENT (ADP)}

The rural integrated agricultural development programmers are aimed at improving the quantity of life in the rural areas through small scale farmers. The planting and preparation of projects is however, the responsibility of the ADPs in the state. The main components of the rural integrated agricultural development programmed according to [19] include the following:-

i) Construction and maintenance of rural roads to facilitate farmer's access to the agro-service centers and markets, and to ease the movement of goods and services throughout the project areas.

ii) Construction of agro-service center where farmers can obtain farm imputes credit and extension services at very close intervals throughout the project areas. 
iii) Provision of seeds, fertilizers, chemical, and mechanical implements for sale on cash or credit basin at the agro-service centers.

iv) Provision of additional extension workers to promote the adaption of new technology for the major crops and livestock suitable for the project areas.

v) Provision of marketing facilities for cash crops which the farmers cannot dispose of richly.

vi) Construction of small earth dams to store water for village use and for livestock and where possible, for small scale irrigation.

vii) Training of staff and farmers in modern farming techniques.

\section{V.8.NIGERIAN AGRICULTURAL CO-OPERATIVE AND RURAL DEVELOPMENT BANK (NACRDB) AND AGRIC CREDIT AND GUARANTEE SCHEME (ACGS)}

A vicious cycle of low output, low level income, low saving and investment resulting again in low level of output is characteristic of most developing economic of which Nigeria is one and is even characteristic of the farming commodities of these economics.[20]reported that the provision of agricultural credit to small scale farmers can help in breaking this cycle. According to [21] the scarcity of credit and input are the major reasons for the non-adoption of high yielding varieties of crops. The author is of the view that it was only when increased credit is made available can further expansion of hectarage under high yielding varieties be possible; hence for an economy which agriculture constituted the mainstay, the need to integrate credit assistance to agricultural production becomes evident ([22]. According to [23], credit determined access to all the resources on which farmers depended. The federal government of Nigeria, in recognition of the need to finance agricultural business directed all licensed banks through central bank of Nigeria (CBN) in 1977 to open bank branches in the rural areas. This is to encourage banking habit, provide agricultural credit with minimal interest and redress the lopsidedness in the availability of banking services in rural areas; farmers are still constrained in their access to credit facilities from banks and other funding sources, NACRDB was established by the federal Government of Nigeria in 1973, with the objective of providing loanable funds to farmers for agricultural development.

\section{V.9.RESEARCH INSTITUTIONS}

Supporting the research institutes by way of funding them for new innovation and technology ideas that would strengthen small scale farmers. Some of the research institutes in Nigeria are:-

National cereal research institute (NCRI) in Badeji Niger State

National root crop research institute (NRCRI) Umudike ,Umuahia

National institute for oil-palm research ( NIFOR) Benin

Nigeria horticultural research institute (NIHORT) Ibadan.

National Rubber Research Institute, Benin.

Cocoa Research Institute Ibadan. Nigeria

\section{Summary And Recommendation}

Nigeria small scale farmers produced the bulk of agricultural output. The situation is likely to remain so for some years to come. They played their important roles under greatdifficulties. They therefore deserved all possible assistance.A major problem was the high cost and non availability of inputs. Urgent effort should be made to find solution to the issue of fertilizer subsidy and distribution. The problem with fertilizer and small scale farmers was not the high price, but the availability. The arrangement for fertilizer distribution was still unsatisfactory. The government should not allow the benefits accrued to small scale farmers to land in the hands of unintended beneficiaries, the hoarders and middle men.Researchers should take the challenges posed by high costs and scarcity of fertilizer with the use of legumes, and cover crops in intercropping, sequential cropping and rotations.Privatization of procurement and distribution of inputs should be viewed with caution.

[1] FAO, 2006. The State of Food and Agric. U.N.FAO Rome.

\section{References}

[2] Elemo, K.A. Vumar, J., Olukosi and Ogunbile A.O, 1988. Review of research work on mixed cropping in the Nig. Savanna. Miscellaneous paper institute for Agric Res. Savanna.

[3] Ani, A.O. 1999. An impact study on the adoption of improved agric. Tech. by groundnut farmers in Itarul L.G.A of Borno, Nig. Nig. J. Rural development: Pg: 19-25.

[4] Oyaide S.O. 2000 Characteristic, Problems and significance of Farmer, pp $2-15$.

[5] Okoro, C.O. 1988 "Farm Settlement Experiment in Eastern Nigeria. The Uzo -Uwani Example.The Nigerian Journal of Ed., vol. 1.No.1.

[6] FAO, 1990 Sustainable Food Production in Sub-Sahara Africa

[7] Onuekwusi,G.C., 2013 Youth Programmes in Extension and Rural Development in Nwachukwu, I.Agricultural Extension and Rural Development .Lamb House Publications, Umuahia,pp148//

[8] Adelekan ,B.A.and Taiwo,A.A.2006. Agricultural Science for Senior Secondary Schools. Spectrum Books Limited Ibadan.. 
[9] Gary J, Akinwuami, A, and Devines J. 2008. Building an Alliance for a Green Revolution in Africa Ann. N.Y. Acad. Sci. 1136: 233 $-242$

[10] IFPRI 2007 - 2020. Focus Briefs on the World's Poor and hungry People (2020 vision Focus Special Ed./ IFPRI Washington D.C.

[11] Njoku,P.C.1999 .Enhancing Youth Participation in Sustainable Agriculture.Lead paper presented at the National Symposium on the 1999 World Food Day at Abuja..

[12] Rahji, M.A.Y 1999. An Analysis of Agric. Credit, Approval/loan size by commercial banks in S. Western.

[13] World Bank, 2007. Wood Development Report 2008: Agric. For Dev.The World Bank Washington, D.C.

[14] Devries J. and G. Toeninessia 2001. Secondly the harven:- Biotechnology, breeding and seed system for Africa crops. CAB, publishing. Walling ford, U.K.

[15] Obibuaku, L.O 1983. Agricultural Extension as a strategy for Agric. Transformation University of Nigeria. Press Nsukka.

[16] Adedoyin ,F.S1996 a manual of Rural Extension Service.Samfad Farm Foundations Ojodu,Lagos

[17] Barner and Yameh 1957. The economics of underdeveloped countries, Cambridge, cup.

[18] Perez, A.T. et al, 1976. An integrated approach to accelerated production of rice and maize in the rain forest zone pp. 2 - 3.

[19] Oyaide, S.O. 1983. Adoption of farm Tech in North Nigeria. A paper prepared for Review meeting, World bank, Washington D.C Jan $10-11$

[20] Adegeye I.O and Dittoh F.O. 1985.Agricultural extension at a strategy for agricultural transformation, University of Nigeria press, Nsukka.

[21] Ijere, M.O. 1975. Role of Government in Accelerated Food production in Nigeria "Symposium on Appropriate Approaches for Accelerated Food.

[22] Crick I.O 1985. Food production situation. A paper presented at the national by imputing of Nigeria ford question organized by the coll. Agric. Dept. of Eco. And Ext. University of agric. Mark Udi 11-12 Dec.

[23] Shepherd, W.A. 1997. Market Power and Economic welfare, Random House N.Y pp. 51. 